\title{
AMALAN AKHLAK KEPALA SEKOLAHDASAR ISLAM DI MALANG MELALUI MURAQABAH, MUHASABAH DAN MUJAHADAH
}

\author{
Triyo Supriyatno \\ trios70@yahoo.com \\ Fakultas Ilmu Tarbiyah dan Keguruan (FITK) UIN Maliki Malang Wan Hasmah Wan \\ Mamatwanhasmah@um.edu.my \\ Fakulti Pendidikan Universiti Malaya (UM) Malaysia
}

\begin{abstract}
Muhasabah is a surveillance system involving the internal control process to ensure alamr al-ma'ruf wa al-nahyu 'an al-munkar implemented in Islamic education. The main purpose of this article is to examine the determinants of akhlak practices through elementary Islamic Education among Two Principal Schools. We're collected data by non-participant observations, semi-structured interviews, documentation and principals' journals. The results of this study showed that the practice of akhlak principals of Elementary Islamic School in Malang through muraqabah (behavioral observation), muhasabah (reflection practice) and Mujahadah (struggle of desires) contributed to the realization of the national education philosophy to produce a generation of school community who are righteous knowledgeable, competent, honorable and contribute to a universalcivilization.
\end{abstract}

Keywords: Muraqabah, Muhasabah, Mujahadah, AkhlakLeadership

\section{Latar Belakang Masalah}

Abdul Halim elᄀMuhammady (1995) menjelaskan bahwa pendidikan dalam Islam menekankan beberapa konsep yaitu; pendidikan seumur hidup, pengembangan seluruh potensi manusia secara terpadu yang mencakup aspek kognitif, afektif dan sosial; melaksanakan kewajiban sebagai hamba Allah dan amanah sebagai khalifah di muka bumi; memakmurkan praktek atas dasar kekompakan dan kesempurnaan iman serta ilmu dan amal saleh untuk mencapai kebahagiaan hidup di dunia dan akhirat. 
Filsafat Pendidikan Islam juga berperan menempatkan gagasan dalam melahirkan individu yang saleh, orang yang beriman dan berkepribadian mulia dengan memliki keseimbangan dari segi material dan rohani (Ahmad Mohd Salleh 2004; Mohd Yusuf 2002; Engku 2007; Hasnan 2008; Kamarul Azmi \& Ab. Halim 2010). Ini sejalan dengan pandangan Al-Attas (1980) yang menjelaskan bahwa hakikat keinsanan mengacu pada manusia sebagai makhluk berkedudukan dan harus diakui oleh makhluk yang lain. Tingkat manusia dilihat pada kelebihan berakal yang diseimbangi dengan rohaniah dan jasmaniah (Hasnan 2008. Keuntungan manusia diidentifikasi melalui kemampuan menggunakan akal dalam memiliki ilmu pengetahuan dalam mengelola alam dengan berhikmah. Ilmu pengetahuan yang diperoleh harus disesuaikan dengan tuntutan rohaniah dan jasmaniah agar keseimbangan bertingkah laku sebagai hamba Allah dan tanggung jawab sebagai khalifah didasarkan pada aqidah, syariah dan akhlak yang sempurna. Sehubungan itu, manusia yang dididik dengan Filsafat Pendidikan Islam diberikan ilmu pengetahuan dengan penghayatan akhlak yang bersifat ketakwaan, keikhlasan, amanah, kasih sayang dan berakhlak mulia (Hamka 2003; Hasnan 2008; Khadijah 2009).

Pendidikan Islam juga memastikan manusia selalu memiliki kekuatan dasar manusia yaitu akal, hati, roh dan jasad. Elemen kekuatan yang dianugerahkan kepada manusia perlu proses pendidikan yang berkelanjutan agar manusia menyadari tentang amanah dan tanggung jawab sebagai hamba dan khalifah. Tanggung jawab manusia sebagai hamba dan khalifah menuntut kepada ilmu pengetahuan dan perilaku yang berteraskan kepada keimanan yang diperkenalkan melalui akhlak Rasulullah saw sebagai contoh tauladan yang terbaik kepada seluruh makhluk terutama yang dikategorikan sebagai insan kamil yang soleh (Hamdani 2007; Rokiah 2007; Hasnan 2008). Usaha memastikan manusia yang memiliki sifat-sifat insan kamil yang saleh membutuhkan penghayatan akhlak yang berkelanjutan. Penghayatan akhlak dalam Islam adalah salah satu aspek yang sangat penting dalam pembentukan muslim yang memiliki kepribadian insan kamil menurut al-Quran dan al-Sunnah (Zaharah 2008). Oleh yang demikian, pembangunan kesadaran berakhlak sangat penting dalam proses penghayatan insan kamil terutama dalam tahap awal remaja yang sering berhadapan dengan krisis identitas diri dan kebanyakan mereka mudah terjerumus ke dalam gejalagejala sosial yang tidak sehat. Untuk mengatasi masalah ini, remaja harus 
disadarkan bahwa mereka harus membangun kepribadian diri dan akhlak yang baik sehingga mereka dapat melewati krisis identitas diri yang dialami ketika usia remaja. Jadi, penerapan amalan akhlak melalui muraqabah, muhasabah, dan mujahadah sebagai mekanisme kontrol dan pengawasan adalah alternatif yang terbaik dalam mengarahkan pemimpin, terutama membangun akhlak yang mulia dan sejalan dengan fitrah dan tujuan Pendidikan Islam.

Pengawasan berbentuk internal berarti kekuatan bertindak muncul dari diri sendiri sebagai hasil dari proses evaluasi diri yang dikenal sebagai muhasabah diri. Praktek ini bertujuan melahirkan seorang yang selalu disiplin dan berusaha membendung diri dari melakukan kemungkaran saat menjalankan tugas harian dan amanah yang dipikul. Muraqabah, muhasabah dan mujahadah juga bertujuan untuk melahirkan kesadaran berakhlak melalui proses penghayatan dan penerapan amanah dan bertanggung jawab sebagai hamba Allah SWT dan menganggap kerja yang dipikul sebagai ibadah yang selalu diberi peringkat di dunia dan di akhirat. Dalam konteks ini, muraqabah, muhasabah, dan mujahadah berperan penting dalam usaha mewujudkan Filsafat Pendidikan Nasional yaitu mengembangkan potensi individu secara menyeluruh dan terpadu untuk mewujudkan insan yang seimbang dan harmonis dari segi intelek, rohani, emosi dan jasmani berdasarkan kepercayaan dan kepatuhan kepada Tuhan. Usaha ini bertujuan untuk melahirkan manusia yang berilmu pengetahuan, terampil, berakhlak mulia, bertanggung jawab dan mampu mencapai kesejahteraan diri serta memberikan kontribusi terhadap keharmonisan dan kemakmuran keluarga, masyarakat dan negara (UUSPN Sisdiknas No.20 tahun 2003).

\section{PERMASALAHAN PENELITIAN}

Tujuan pendidikan Islam adalah melahirkan manusia yang baik dan membawa kebaikan (Ibn Khaldun 1993; Al-Attas 1978; Nasir 2002), manusia yang memiliki kesempurnaan pribadi (Muhammad Utsman 1987; Abdurrahman 1995), manusia yang menyadari hubungannya dengan Allah, alam dan manusia (al - Shaibani 1975; Zawawi 1996), menyingkap hakikat keberadaan sebagai hamba Allah dan khalifah di muka bumi, menerima keunggulan ayat - ayat Allah, membangun sikap untuk melihat kehidupan dari kaca mata agama dan belajar membuka hati untuk menerima cahaya dan rahmat Allah yang kekal abadi (Shaikh Abdul Mabud 1999; Nasir 2002). Oleh yang demikian, manusia yang dihasilkan melalui Pendidikan Islam sesuai adalah 
manusia yang memiliki pribadi dan akhlak yang mulia sesuai dengan tujuan pengutusan Rasulullah saw (Al-Shaibani 1975). Hasil pencapaian tujuan pendidikan Islam tergambar melalui aplikasi pertumbuhan yang menyeluruh dan persatuan dalam pribadi murid (Al-Shaibani 1975) dengan kekompakan antara iman, ilmu dan amal saleh (Mohd Kamal 1979), penghayatan dan kepekaan terhadap Islam (Syed Ali Ashraf 1997), serta penghayatan akhlak yang mulia pada diri seseorang murid (Al - Abrasyi 1974; Jalaluddin \& Usman 1994; Azhar 2006). Tujuan-tujuan tersebut memungkinkan murid menjalani kehidupan dengan bertunjangkan akidah Islam (iman dan ihsan) pada setiap waktu untuk mencapai kebahagiaan di dunia dan akhirat (Mohd Kamal 1979; Jalaluddin \& Usman 1994 ; Azhar 2010). Namun, penurunan nilai akhlak memiliki kaitan dengan kerusakan tujuan pendidikan Islam. Ini dinyatakan Muhammad Iqbal (dalam Al-Nadwi 1987) bahwa penurunan nilai akhlak adalah gejala kehilangan pertimbangan potensi diri manusia; timbul kesenjangan yang sangat luas antara aspek lahir dan batin, akal dan hati, ilmu dan akidah; hilang jati diri, lemah keyakinan dan harapan; keluar dari keyakinan kepada agama dan Allah; akal yang dangkal dan hati yang keras dari menerima kebenaran; agama; siasah; akal dan hati hanya berfokus materi; dan hidup diselubungi kebekuan dan kerusakan dalam sesuai syariat Islam.

Penyebab gejala kemerosotan akhlak juga dikaitkan dengan faktor kelemahan iman dan krisis nilai yang dipengaruhi oleh paham sekularisme (Zaizul et. Al . 2011). Ini karena paham sekularisme menjadi penyebab segala bentuk kejahatan yang terjadi di dunia memiliki kaitan dengan suatu kondisi yang ada dalam pemikiran manusia yaitu ' cinta dunia ' yang menggantikan tempat ' cinta Allah '. Kondisi ini sejalan dengan pendidikan sekuler yang menolak atau tidak mengutamakan faktor keberadaan Tuhan dalam pendidikan dan mengesampingkan referensi kepada Tuhan yang dianggap tidak relevan dan 'out of fashion' dalam pendidikan masa kini (Sheikh Abdul Mabud. 1999; Zakaria 1999; Hassan 2003; Roslan \& Nosiah 2007). Sheikh Abdul Mabud (1999) juga menggambarkan pendidikan sekuler telah berhasil mempengaruhi pemikiran dan budaya masyarakat muslim dengan menyebabkan hati menjadi keras untuk menerima sumber kebijaksanaan yang mutlak yaitu dari Allah Taala, dan menutupi jiwa dengan kegelapan kebodohan. Ini sejalan dengan perkembangan pendidikan yang memiliki konsep dualisme antara agama dan sekuler. Konsep dualisme telah menjadikan pendidikan agama dibatasi pada penyampaian informasi-informasi 
agama yang sempit (ibadah dan ritual) yang tidak terhubung dengan masyarakat dan kehidupan dan sebaliknya pendidikan sekuler (untuk hal-hal kehidupan dan masyarakat ) tidak pula dihubungkan dengan nilai-nilai agama. Implikasi dari pendidikan konsep dualisme telah melahirkan kelompok tertentu dalam masyarakat yang mencemooh agama dan perkembangannya, melahirkan dua kelompok manusia yang berbeda pola pemikiran dan tindakan, lemah akidah dan pegangan terhadap nilainilai Islam dalam kehidupan serta melahirkan golongan muslim yang lemah di dalam kepemimpinan dan tidak berakhlak (Al-Nadwi 1987; Abdul Halim El-Muhammady 1984; Mohd Kamal Hassan 1988b; Rosnani 1996; Azhar 2006; Roslan \& Nosiah 2007; Mat Saad 2011).

Selain itu, pendidikan sekuler juga telah memperkenalkan pendidikan moral yang dianggap lebih subjektif. Ini karena pendidikan moral berdasarkan naluri moral individu dan tidak mementingkan penghayatan nilai kebenaran yang objektif serta komprehensif sebagaimana yang telah digariskan oleh al-Quran. Menurut Shaikh Abdul Mabud (1999), pendidikan moral sebenarnya mengalami kebingungan nilai, hilang tujuan dan kepastian serta gagal mengidentifikasi kebaikan yang terkandung dalam nilai-nilai yang tetap dan mutlak. Namun, keberhasilan paham pendidikan sekuler telah berkembang ketika Pendidikan Islam berhadapan dengan fenomena kurang respon terhadap mata pelajaran pendidikan Islam dalam kalangan murid-murid yang beragama Islam. Fenomena ini adalah suatu hal yang sangat disesalkan karena terjadi pada waktu masyarakat Islam sangat membutuhkan generasi muda yang memiliki pendidikan agama Islam yang mantap, dan berakhlak dengan akhlak Islam sehingga mereka mampu menghadapi ancaman-ancaman sekularisme, materialisme, ateisme dan hedonisme yang menguasai lingkungan mereka pada masa kini (Hassan 2003; Azhar 2006; Roslan \& Nosiah 2007). Oleh karena itu, penelitian ini dilakukan untuk mengidentifikasi komponen amalan akhlak yang dapat dijadikan praktek kontrol diri dalam mempengaruhi penghayatan akhlak seluruh warga sekolah. Secara langsung penelitian ini adalah alternatif yang wajar diketengahkan dalam usaha mengatasi gejala kemerosotan akhlak dalam kalangan kepala sekolah dan warga sekolah di semua jenjang sekolah.

\section{TUJUAN PENELITIAN}

Penelitian ini bertujuan untuk mengetahui tahap amalan akhlak yang terdiri 
daripada komponen amalan akhlak melalui muhasabah al-nafs yaitu muraqabah (pemerhatian tingkah laku), muhasabah (perhitungan amalan), dan mujahadah (penentangan nafsu) dalam kalangan kepala sekolah dasar Islam di Malang.

\section{ERANGKA TEORI PENELITIAN}

Penelitian ini menggunakan teori Imam Ghazali (2004) yang menekankan pentingnya amalan akhlak seorang muslim melalui tiga tahap, yaitu: tahap muraqabah, muhasabah, dan mujahadah. Ketiga tahapan ini dapat digambarkan sebagai berikut:

Gambar 1: Kerangka teori Amalan Akhlak berdasarkan teori amalan akhlak

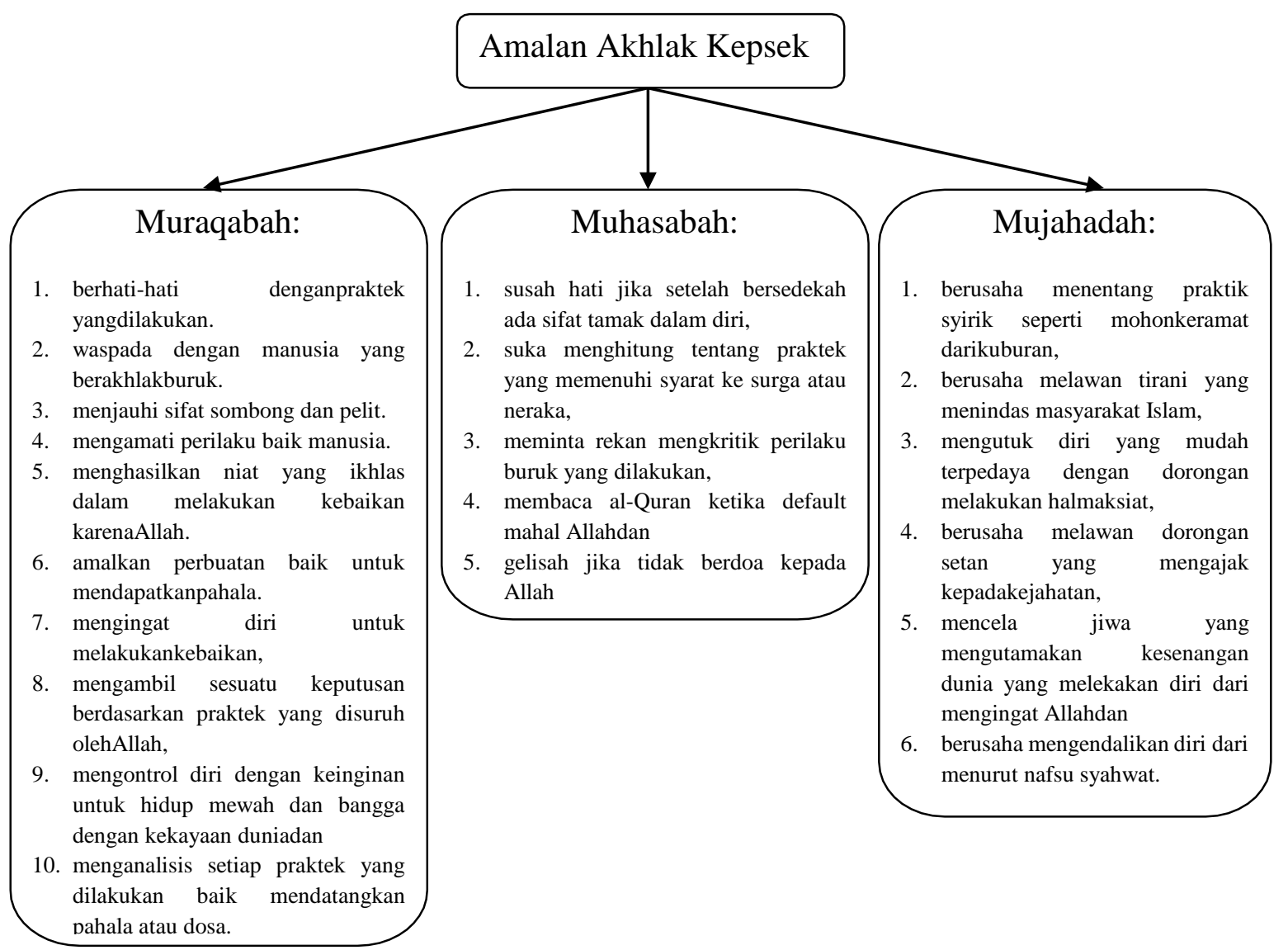

Imam Ghazali (2004)

\section{METODE PENELITIAN}

Penelitian ini menggunakan metode kualitatif. Metode ini telah dipilih dan digunakan dalam penelitian ini adalah untuk memahami, menjelaskan, menjelajahi dan membuat pengungkapan tentang fenomena penelitian (Creswell, 2008). Fenomena yang dimaksud dalam penelitian ini adalah praktek akhlak kepala sekolah di 
dua Sekolah Dasar Islam di Malang. Penelitian ini diharapkan akan dapat memberikan gambaran yang lebih lengkap tentang apa yang terjadi sebenarnya dalam kerja lapangan (Fraenkel \& Wallén,2007).

Tiga teknik pengumpulan data telah dipilih dan digunakan untuk mengumpulkan data dalam penelitian kualitatif ini, yaitu wawancara (interview), pengamatan (observation), dan bukti dokumen (documentation) (Frankel, 2007). Adapun untuk observasi menggunakan non-participant observations, interview menggunakan semistructured interviews, dan dokumentasi menggunakan documentation and principals' journals.

\section{Gambar 2: Prosedur Penganalisisan Data Kajian Kualitatif}

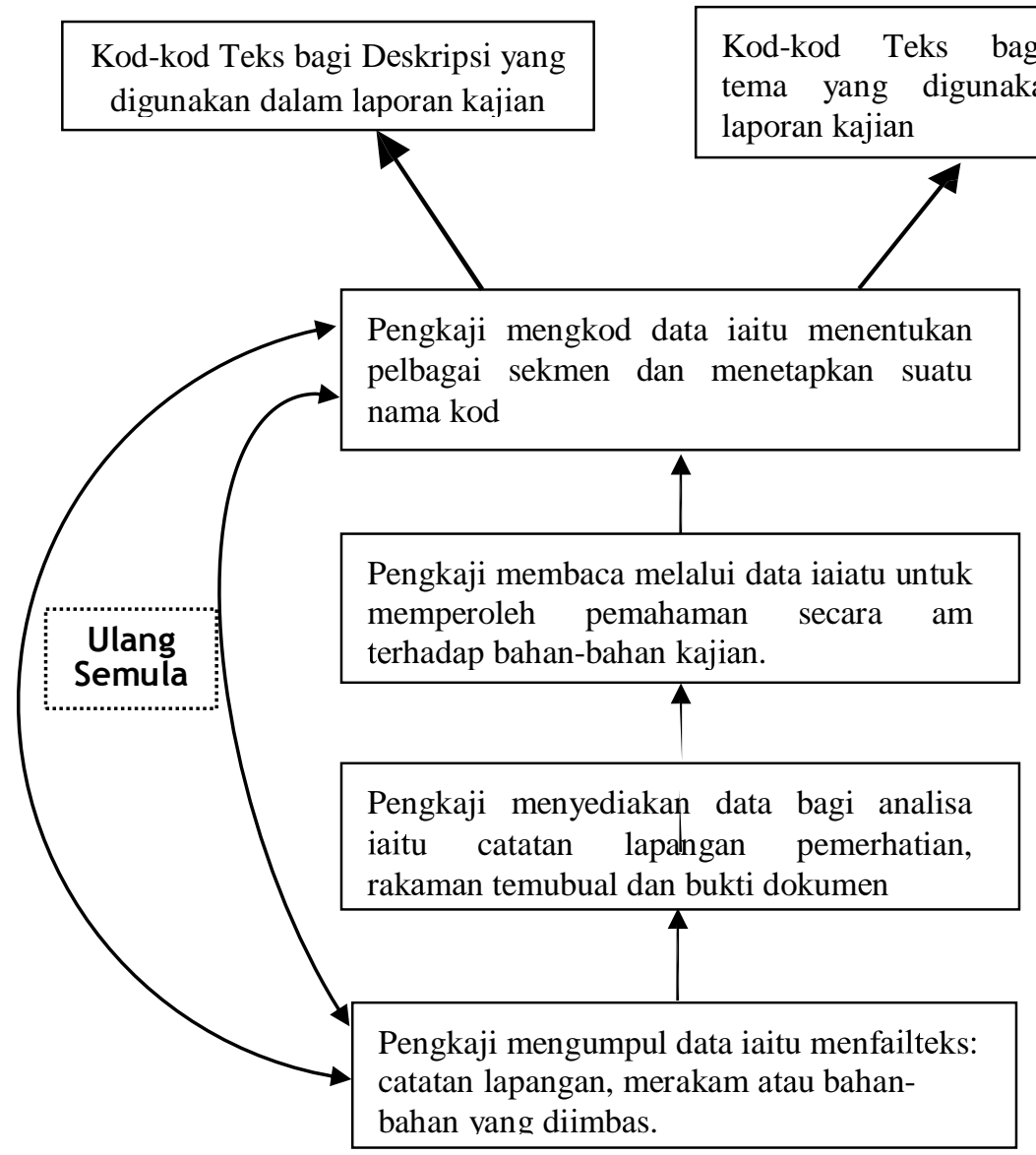

Sumber: Ubah suai daripada Creswell (2008) dalam Triyo Supriyatno (2014). 


\section{PEMBAHASAN HASIL PENELITIAN}

\section{Muraqabah (Pemerhatian Tingkah laku)}

Muraqabah atau pengamatan perilaku melibatkan aktivitas diri dengan menyadari bahwa segala perilaku di bawah pengamatan kekuasaan Allah SWT (AlWaqiah: 63-64, 68-69, al-An'am: 50). Muraqabah bertujuan untuk memastikan segala perilaku manusia adalah bermatlamatkan kepada ketaatan kepada Allah SWT (AlBaqarah: 238,285, Ali-Imran: 17,146, al-Maidah: 7, al- Nisa: 69, al-Maidah: 7). Muraqabah juga dapat melindungi manusia dari terjebak dengan was-was setan yang bermotifkan kepada dorongan menyesatkan manusia dari mentaati Allah SWT (AlBaqarah: 36, al-Nahl: 98, al-A'raf: 53, al-Haq: 53). Oleh karena itu, muraqabah dapat memastikan diri selalu mematuhi amar makruf dan meninggalkan kemungkaran yang telah ditentukan oleh Allah SWT (Al- Baqarah: 160, al-Nisa: 16, al-Maidah: 62,68, 100, Hud 122). Tabel 1 menunjukkan tinjauan analisis pemerhatian untuk komponen muraqabah (pengamatan perilaku) yang terdiri dariberikut:

\section{Tabel 1 Tinjauan Analisis Pemerhatian terhadap Amalan Akhlak (melalui Muraqabah)}

\begin{tabular}{|l|l|l|}
\hline & \multicolumn{1}{|c|}{ ItemPertanyaan } & \multicolumn{1}{|c|}{$\begin{array}{c}\text { Kepala } \\
\text { Sekolah }\end{array}$} \\
\hline 1. & Berhati-hati dengan praktek yang dilakukan & A \\
\hline 2. & Waspada dengan manusia yang berakhlak buruk & B \\
\hline 3. & Menjauhi sifat sombong dan pelit & A danB \\
\hline 4. & Mengamati perilaku baik manusia & A \\
\hline 5. & $\begin{array}{l}\text { Menghasilkan niat yang ikhlas dalam melakukan kebaikan karena } \\
\text { Allah }\end{array}$ & A dan B \\
\hline 6. & Amalkan perbuatan baik untuk mendapatkan pahala & A danB \\
\hline 7. & Mengingat diri untuk melakukan kebaikan & A danB \\
\hline 8. & Mengambil keputusan berdasarkan praktek yang disuruh oleh Allah & A danB \\
\hline 9. & $\begin{array}{l}\text { Mengontrol diri dengan keinginan untuk hidup mewah dan bangga } \\
\text { dengan kekayaan dunia }\end{array}$ & A \\
\hline 10. & $\begin{array}{l}\text { Menganalisis setiap praktek yang dilakukan baik mendatangkan } \\
\text { Pahala atau dosa }\end{array}$ & A danB \\
\hline
\end{tabular}

Hasil tinjauan analisis pengamatan membuktikan bahwa komponen muraqabah yang terdiri dari sepuluh item telah diberi prioritas sebagai factor yang pertama dari enam komponen dalam muhasabah. Antara item-item yang membentuk faktor pertama melalui muraqabah adalah praktek berhati-hati dengan perbuatan yang dilakukan, waspada dengan manusia yang berakhlak buruk, menjauhi sifat sombong dan pelit, mengamati perilaku baik manusia, menghasilkan niat yang ikhlas dalam 
melakukan kebaikan karena Allah, amalkan perbuatan baik untuk mendapatkan pahala, mengingat diri untuk melakukan kebaikan, mengambil sesuatu keputusan berdasarkan praktek yang disuruh oleh Allah, mengontrol diri dengan keinginan untuk hidup mewah dan bangga dengan kekayaan dunia dan menganalisis setiap praktek yang dilakukan baik mendatangkan pahala atau dosa (Al-Baqarah: 238,285, Ali-Imran: 17,146, al-Maidah: 7, al-Nisa: 69, al-Maidah:7).

Muhasabah ( Perhitungan Praktek)

Muhasabah atau perhitungan praktek berarti membuat pertimbangan terhadap praktek yang dilakukan dalam urusan kehidupan dengan merenung kembali dan memperbaiki praktek demi karena Allah SWT Muhasabah juga dikenal sebagai muhasabah diri dalam mengenali diri sendiri dengan segala kekurangan yang dimiliki . Tujuannya untuk mengenal batas diri hingga mencapai jiwa yang tenang. Jiwa yang tenang adalah jiwa yang memiliki keimanan dan ketenteraman dalam mengenal Allah SWT (Abu Umar Basyir 2005 ; Ibn Sina 2009 ; Zuridan 2010 ) .

Komponen muhasabah menunjukkan pendekatan yang sederhana tinggi dipraktekkan oleh murid dalam pembelajaran Pendidikan Islam . Namun ada juga yang menjadikan amalan muhasabah diri sebagai praktek harian dan kelaziman dalam hidup mereka setelah menerima proses pembelajaran Pendidikan Islam secara informal di asrama. Hasil penelitian ini sejalan dengan hasil penelitian oleh Azhar ( 2006 ) dalam penelitian strategi pembelajaran pengaturan diri dalam Pendidikan Islam yang menjelaskan bahwa murid sekolah menengah di Sarawak mengunapakai strategi pengaturan diri ketika menghadapi masalah atau tekanan dalam kehidupan . Komponen muhasabah ( perhitungan amalan ) dalam hisbah diklasifikasikan dalam tinjauan analisis faktor seperti yang ada dalam Tabel 2 berikut :

Tabel 2 Tinjauan Analisis pengamatan terhadap Muhasabah

\begin{tabular}{|l|l|l|}
\hline & \multicolumn{1}{|c|}{ ItemPertanyaan } & $\begin{array}{c}\text { Kepala } \\
\text { Sekolah }\end{array}$ \\
\hline 1. & Susah hati jika setelah bersedekah ada sifat tamak dalam diri & A \\
\hline 2. & $\begin{array}{l}\text { Suka menghitung tentang praktek yang memenuhi syarat sayake } \\
\text { surga atau neraka }\end{array}$ & $\mathrm{B}$ \\
\hline 3. & Meminta teman saya mengkritik perilaku buruk yang saya lakukan & A danB \\
\hline 4. & Membaca al-Quran ketika saya lalai mengingat Allah & A dan B \\
\hline 5. & Gelisah jika tidak berdoa kepada Allah & A dan B \\
\hline
\end{tabular}


Tinjauan analisis faktor turut menjelaskan komponen muhasabah dalam amalan akhlak. Ada lima item yang menjelaskan bahwa praktek yang terbentuk terdiri dari: susah hati jika setelah bersedekah, ada sifat tamak dalam diri, suka menghitung tentang praktek yang memenuhi syarat ke surga atau neraka, meminta rekan mengkritik perilaku buruk yang dilakukan, membaca al-Quran ketika default mahal Allah dan gelisah jika tidak berdoa kepada Allah. Praktek tersebut membentuk komponen muhasabah bertujuan membentuk disiplin diri sehingga selalu membuat evaluasi diri dalam menentukan corak kehidupan.Mujahadah (Perlawanan Nafsu)

Mujahadah atau penentangan nafsu berarti berusaha keras melawan keinginan hawa nafsu. Istilah mujahadah berasal daripadaperkataan jihad, yaitu berusaha dengan sepenuh kesungguhan, kekuatan dan kesanggupan pada jalan yang diyakini benar. AlGhazali (2004) menjelaskan bahwa mujahadah secara dasarnya melawan hawa nafsu dengan menundukkan hawa nafsu untuk mengikuti kehendak Allah dalam setiap hal. Mujahadah dilakukan untuk mengontrol kekuatan amarah dan syahwat (keinginan) dalam diri manusia yang mengumpulkan sifat-sifat tercela dan selalu mendorong manusia untuk melakukan perbuatan yang jahat.

Al-Ghazali (2004) menjelaskan bahwa mujahadah secara dasarnya melawan hawa nafsu dengan menundukkan hawa nafsu untuk mengikuti kehendak Allah dalam setiap hal. Mujahadah dilakukan untuk mengontrol kekuatan amarah dan syahwat (keinginan) dalam diri manusia yang mengumpulkan sifat-sifat tercela dan selalu mendorong manusia untuk melakukan perbuatan yang jahat. Hasil penelitian ini menunjukkan praktek mujahadah dilakukan melalui keyakinan aqidah dan praktek ibadah yang telah ditetapkan (Zuridan 2010; Muhammad Zul Helmi 2010) agar diri menjadi lebih dekat kepada takwa (Roslan \& Nosiah 2007). Dalam hal ini, mujahadah lebih kepada mengendalikan diri dari mengikut perasaan dan melawan diri dari terpengaruh dengan bisikan setan (Al-Baqarah: 155, Al-Maidah: 30, An-Nisa: 10, Al-An'am: 119, Yusuf : 53, Al-Ra'ad: 37, Maryam: 59, Al Ankabut: 8,29, Al-A'raf: 81, Al-Naml: 55, Al-Ra'ad: 33, An-Nisa': 27).Tinjauan anlisis pengamatan terhadap mujahadah (penentangan nafsu) memperoleh hasil sebagaimana dalam Tabel 3 di bawah: 
Tabel 3 Tinjauan Analisis pengamatan terhadap Mujahadah

\begin{tabular}{|c|l|l|}
\hline & \multicolumn{1}{|c|}{ ItemPertanyaan } & \multicolumn{1}{|c|}{$\begin{array}{c}\text { Kepala } \\
\text { Sekolah }\end{array}$} \\
\hline 1. & $\begin{array}{l}\text { Berusaha menentang praktik syirik seperti mohon keramatdari } \\
\text { kuburan }\end{array}$ & A dan B \\
\hline 2. & Berusaha melawan tirani yang menindas masyarakat Islam & A \\
\hline 3. & $\begin{array}{l}\text { Mengutuk diri yang mudah terpedaya dengan dorongan melakukan } \\
\text { hal maksiat }\end{array}$ & A dan B \\
\hline 4. & Berusaha melawan dorongan setan yang mengajak kepada kejahatan & A dan B \\
\hline 5. & $\begin{array}{l}\text { Mencela jiwa yang mengutamakan kesenangan dunia yang } \\
\text { melekakan diri dari mengingat Allah }\end{array}$ & A \\
\hline 6. & Berusaha mengendalikan diri saya dari menurut nafsu syahwat & A \\
\hline
\end{tabular}

Dalam konteks penelitian ini, analisis pengamatan menunjukkan komponen mujahadah terdiri dari: berusaha menentang praktik syirik seperti mohon keramat dari kuburan, berusaha melawan tirani yang menindas masyarakat Islam, mengutuk diri yang mudah terpedaya dengan dorongan melakukan hal maksiat, berusaha melawan dorongan setan yang mengajak kepada kejahatan, mencela jiwa yang mengutamakan kesenangan dunia yang menjauhkan diri dari mengingat Allah dan berusaha mengendalikan diri dari menurut nafsu syahwat.

Secara rumusannya, hasil penelitian ini secara khusus menunjukkan bahwa muhasabah dalam Pendidikan Islam bertujuan untuk memantau perilaku dari mendekati sifat-sifat buruk dalam diri manusia dan membuat refleksi diri untuk menciptakan kesadaran diri dengan menanamkan nilai-nilai taqwa dalam diri (Malik, 2000). Dalam proses ini, murid yang berlatih hisbah otomatis berupaya mengawasi diri dengan motivasi untuk menghayati ajaran Islam dalam diri dari waktu ke waktu (Azhar, 2006). Selain itu hisbah otomatis juga berperan melahirkan murid yang memiliki tujuan yang jelas tentang keberhasilan dalam bidang akademik dengan kemampuan melihat masa depan secara optimis (Zimmerman, 2002). Ini sesuai dengan hasil penelitian yang menjelaskan bahwa kepala sekolah SDI di Malang memang mengamalkan amalan akhlak melalui praktek muraqabah (pengamatan perilaku), muhasabah (perhitungan amalan), dan mujahadah (penentangan nafsu) selama berada di sekolah sebagai pendekatan pembelajaran akhlak dalam pendidikan agama Islam dan budi pekerti. 


\section{KESIMPULAN}

Secara keseluruhan, hasil penelitian ini memberi gambaran bahwa amalan akhlak kepala sekolah SDI di Malang melalui muraqabah, muhasabah dan mujahadah terjadi secara informal dalam lingkungan sekolah tetapi dipraktekkan dalam bentuk penghayatan ajaran Islam dalam kehidupan sehari-hari. Namun begitu, budaya ilmu serta budaya pembelajaran yang sudah ada dalam praktek pengajaran dan pembelajaran Pendidikan Agama Islam dan Budi Pekerti memberi kontribusi besar terhadap keberadaan praktek amalan akhlak dalam mempengaruhi penghayatan akhlak peserta didik dan warga sekolah. Sekaligus, hasil penelitian ini menggambarkan bahwa amalan akhlak terbentuk secara langsung atau tidak langsung dari proses uswatun hasanah dari kepala sekolah kepada seluruh warga sekolah.

Hasil penelitian ini memiliki relevansi dengan konsep kesempurnaan diri yang diperkenalkan oleh Maslow (1943). Dalam teori tersebut, konsep kesempurnaan diri adalah usaha untuk mencapai potensi diri yang berarti kepada seseorang. Menurut Maslow (1943), manusia dilahirkan dengan kekuatan internal yang mampu menghasilkan potensi diri yang maksimal dengan melalui beberapa tahap. Dalam konteks penelitian ini, kekuatan internal yang dimaksudkan oleh Maslow (1943) diterjemahkan sebagai proses muhasabah yang memiliki tiga tahap yaitu muraqabah (pengamatan perilaku), muhasabah (perhitungan amalan ), dan mujahadah (penentangan nafsu). Ketiga tingkat dalam amalan akhlak yang dilakukan bertujuan untuk mencapai kesempurnaan jiwa yang tenang (mutma'innah). Dalam penelitian ini menjelaskan bahwa konsep kesempurnaan diri manusia dalam Islam adalah memiliki jiwa mutma'inah yaitu jiwa yang paling kokoh dan paling sempurna karena mampu menyadari tentang kenyataan hidup dengan kesadaran mengenal sumber dari segala sumber kehidupan yaitu Allah SWT (Amina Noor 2008; Yatimah 2010; Ibn Sina 2009).

Kepala sekolah yang berlatih dalam amalan akhlak melalui tiga tahap tadi dapat mengidentifikasi diri secara optimal melalui potensi intelektual yang melibatkan hati, jasmani, akal, rohani, nafsu dan jiwa. Integritas dan keseimbangan potensi intelektual dalam amalan akhlak tadi otomatis dapat mendidik dirinya untuk menganalisis diri, dan seterusnya memperbaiki kelemahan diri untuk membangun potensi intelektual yang cemerlang di dunia dan akhirat. Adanya amalan akhlak 
melalui muraqabah, muhasabah dan mujahadah adalah salah satu strategi untuk merealisasikan Filsafat Pendidikan Islam yaitu mengembangkan potensi individu secara menyeluruh dan terpadu untuk mewujudkan insan yang seimbang dan harmonis dari segi intelek, rohani, emosi dan jasmani berdasarkan kepercayaan dan kepatuhan kepada Tuhan. Usaha ini adalah bertujuan untuk melahirkan sosok pemimpin yang berilmu pengetahuan, terampil, berakhlak mulia, bertanggung jawab dan mampu mencapai kesejahteraan diri serta memberikan kontribusi terhadap keharmonisan dan kemakmuran keluarga, masyarakat dan negara. Oleh yang demikian, penelitian ini memiliki kaitan dengan Filsafat Pendidikan Islam. Hasil penelitian menjelaskan bahwa amalan akhlak melalui muraqabah, muhasabah, dan mujahadah diidentifikasi sebagai suatu upaya membentuk akhlak pemimpin dalam meghayati ilmu Pendidikan Islam. Dengan demikian, hasil penelitian ini dapat dimanfaatkan untuk kepala sekolah menengah dalam mengembangkan fitur dan praktek amalan akhlak dalam pengembangan akhlak peserta didik dan warga sekolah di sekolah menengah. 


\section{DAFTAR PUSTAKA}

Abdul Halim El-Muhammady. (1984). Pendidikan Islam: Skop dan matlamatnya. Jurnal Pendidikan Islam, 1: 10- 23.

Abdul Halim El-Muhammady. (1991). Pendidikan Islam, falsafah, disiplin dan peranan pendidikan. Kuala Lumpur: Dewan Bahasa dan Pustaka.

Abdul Halim El-Muhammady. (1995). Pendidikan Islam di Malaysia. Jurnal Pendidikan Islam 7 (2): 155-164.

Abdul Rahman Umdirah. (1995). Membentuk Insan Kamil-Motivasi PendidikanIslam Terj. Kuala Lumpur: Darul Nu'man.

Abdul Salam Yussof. (2003). Imam al-Ghazali: Pendidikan berkesan. Kuala Lumpur: Utusan Publications \& Distributors Sdn.Bhd.

Abu Umar Basyir. (2005). Suci hati. Muhammad Albani (Pnyt). Indonesia: Al- Qowam. Ahmad Faried. (2004). Menyucikan jiwa: Konsep ulama Salaf. M. Azhari Hatim. Terj. Surabaya: RisalahGusti.

Ahmad Mohd Salleh. (2004). Pendidikan Islam: Falsafah,Sejarah dan Kaedah Pengajaran dan pembelajaran. Kuala Lumpur: Fajar Bakti Sdn.

Al-Abrashi, Muhammad 'Athiyah. (1974). Dasar-dasar Pokok Pendidikan Islam. Terj.Jakarta: Penerbit Bulan Bintang.

Al-Attas, Syed Muhammad Al-Naquib. (1978). Islam and Secularism. Kuala Lumpur: Muslim Youth Movement of Malaysia.

Al-Attas, Syed Muhammad Naquib. (1980). The concept of education in Islam. Kuala Lumpur: Angkatan Belia Islam Malaysia (ABIM).

Al-Buti, Said Ramadhan. (1991). Fiqh serah nabawiyah. Beirut: Darul Fikri.

Al-Darini, 'Abdul Aziz. (2000). Thaharatulqulub alkhudhuu' li'alaamal-ghuyub.

Mudzakir AS. Terj. Pembersih kalbu. Bandung: Penerbit Pustaka Bandung.

Al-Ghazali, al-Imam Abu Hamid Muhammad ibn al-Ghazali. (2004). Ihya' 'ulum aldin. Jilid 1-5. Qaherah: Dar alAfaq al- 'Arabiyyah.

Al-Nadwi, Syed Abu Al-Hassan Ali. (1987). Ke arah pendidikan Islam yang tulin. Terj. Alor Star: Pustaka Ikhwan.

Al-Razi, Muhammad ibnu Umar. (2000). Ruh dan jiwa: Tinjauan filosofis dalam perspektif Islam. H.Mochtar Zoerni \& Joko S. Kahhar. Terj. Surabaya: RisalahGusti.

al-Shaibani, Umar Muhammad Al-Toumi. (1975). Falsafah Al-Tarbiyyah AlIslamiyyah. Libya: Al-Mansya'ah AlSya ${ }^{c}$ biyyah li Al-Nasyr wa Al-Tauzic waiclan.

Amina Noor. (2008). Bimbingan mengenal diri untuk remaja. Kuala Lumpur: Utusan Publications \& Distributors Sdn.Bhd.

Ansari, Zafar Afaq (Eds.). 1992. Qur'anic concepts of human psyche. Islamabad: The International Institute of IslamicThought.

Asar Abdul Karim \& Ahmad Fazullah Mohd Zainal Abidin. (2008). Kepentingan Pendidikan Rohani dalam Pembangunan dan Pendidikan Islam. Prosiding Wacana Pendidikan Islam Peringkat Kebangsaan Siri ke-6. Anjuran Fakulti Pendidikan UKM dengan kerjasama Majlis Islam Sarawak \& Jabatan Pelajaran NegeriSarawak.

Azhar Ahmad. (2006). Strategi pembelajaran pengaturan kendiri Pendidikan Islam 
dan penghayatan akhlak pelajar sekolah menengah. Tesis $\mathrm{PhD}$, Pendidikan Islam, Universiti KebangsaanMalaysia.

Burns, R.B. (1979). The self concept theory, measurement, development and behaviour. London: Longman. Chua Yan Piaw. (2006). Kaedah penyelidikan. Selangor: Mc Graw Hill Education.

Cooper, D. \& Schindler, P. (2003). Business research methods. $8^{\text {th }}$ Edition. New York:McGraw-Hill.

Engku Ahmad Zaki Engku Alwi. (2007). Membangun modal insan melalui pemantapan akidah. Putrajaya: Jabatan Kemajuan Islam Malaysia, Jabatan Perdana Menteri.

Hair, J., Black, W., Babin, B. \& Anderson, R. (2010). Multivariate data analysis: A

global perspective. $7^{\text {th }}$ Edition. Uper Saddle River, NJ: Pearson Education. Hamdani Bakran Adz-Dzakiey. (2007). Psikologi kenabian: Menghidupkan potensi

dan kepribadian kenabian dalam diri. Yogyakarta: Beranda Publishing. Hamka. (1980). Sejarah umat Islam. Kuala Lumpur: Pustaka Antara.

Hamka. (2003). Lembaga budi: Perhiasan insan cemerlang. Selangor: Pustaka Dini

Sdn Bhd.

Hamzah Yacqub. (1995). Ilmu makrifah sumber kekuatan dan ketenteraman hati. Kuala Lumpur: Darul Taqwa.

Hasnan Kasan. (2008). Pendidikan remaja Muslim. Putrajaya: Jabatan Kemajuan

Islam Malaysia, Jabatan Perdana Menteri.

Hassan Haji Mohamood (2003). Penyalahgunaan dadah di kalangan remaja negeri

Kelantan: Penelitian khusus di Pusat Serenti (W) Kemumin. DisertasiSarjana

Usuluddin. Jabatan Sejarah dan Tamadun Islam,BahagianPengajian usuluddin, Akademi Pengajian Islam, Universiti Malaya, Kuala Lumpur. Ibn Khaldun. (1993). Mukadimah Ibn Khaldun. Terj. Kuala Lumpur: Dewan Bahasa dan Pustaka. Ibn Sina. (2009). Psikologi Ibn Sina. M.S. Nasrulloh. Terj. Indonesia: Pustaka Hidayah.

Ibrahim Abdul Muqtadir. (2010). Kebijaksanaan Luqman al-Hakim: 12 cara

membendung kerosakan akhlak. Kuala Lumpur: Alam Raya Entreprise. Jalaluddin \& Usman Said. (1994). Filsafat Pendidikan Islam: Konsep dan perkembangan pemikirannya. Jakarta: PT Raja Grafindo Persada.

Kamarul Azmi Jasmi \& Ab. Halim Tamuri. (2010). Pendidikan Islam: Kaedah pengajaran dan pembelajaran. Skudai: Penerbit Universiti Teknologi Malaysia.

Kementerian Pelajaran Malaysia. (1998). Laporan jawatankuasa kabinet mengkaji pelaksanaan dasar pelajaran 1979. Kuala Lumpur: Dewan Bahasa \&Pustaka.

Khadijah Abdul Razak. (2009). Pembentukan insan berakhlak mulia daripada 
persepektif falsafah Pendidikan Islam. Prosiding Wacana Pendidikan Islam Siri Ke-9 (peringkat Nusantara). Gontor: Institut Studi Darussalam Gontor, Indonesia.

Lutpi Ibrahim. (1983). Al-Muhasibi: Panduan bakal sufi. Kuala Lumpur: Penerbitan Sarjana. Malik Banikir Badri. (2000). Contemplation. Kuala Lumpur: Madeena Books.

Mardzelah Makhsin , Mohamad Fadhli Ilias, Mohd. Aderi Che Noh, [2014], AMALAN HISBAH KENDIRI DALAM PENDIDIKAN ISLAM: KAJIAN TERHADAP MURID-MURID SEKOLAH MENENGAH DI KEDAH, dalam Jurnal The Online Journal of Islamic Education, January

2014, Vol. 2 Issue 50.

Maslow, A.H. (1943). A theory of human motivation. Psychology Review, July: 388-

389.

Mat Saad Abdul Rahman. (2011). Kedudukan orang bukan Islam dalam sejarah pemerintahan Islam. Putrajaya: Jabatan Kemajuan Islam Malaysia.

Mohd Kamal Hassan. (1979). Ke arah penyerapan unsur-unsur Islam dalam dasar pendidikan negara, kertas kerja yang dibentangkan dalam Majlis Ulangtahun ke25 Pengajian Melayu, Okt. 1978-Sept. 1979.

Mohd Kamal Hassan. (1988). Pendidikan dan pembangunan: Satu perspektif bersepadu. Kuala Lumpur: Dewan Bahasa \& Pustaka.

Mohd Kamal Hassan. (1994). Penyerapan unsur Islam melalui sistem pendidikan negara. Dlm. Abu Bakar Nordin (Pnyt.) Reformasi pendidikan dalam menghadapi cabaran 2020, 143-156. Kuala Lumpur: Nurin Enterprise. Mohd. Yusuf, Ahmad. (2002). Falsafah dan sejarah Pendidikan Islam. Kuala

Lumpur: Penerbit Universiti Malaya. Mok Soon Sang. (2009). Literatur dan kaedah penyelidikan. Petaling Jaya: Penerbitan Multimedia Sd.Bhd.

MostafaKamalMokhtar.(2009).Pembangunanrohanimenurutperspektiftasawufdan psikologi moden. Dlm. Khaidzir Ismail. Psikologi Islam: Falsafah, teori dan aplikasi. Kula Lumpur: iBook Publication SdnBhd.

Mostafa Kamal Mokhtar. (1994). The treatise on the knowledge about the rational soul and its states by Ibn Sina: A critical edition and annotated translation. AKADEMIKA, 44:45-71.

Mostafa Kamal Mokhtar. (1995). Pembangunan rohani: Huraian kritis daripada aspek kerohanian. Dlm. Mostafa Kamal Mokhtar, Noor Rahamah Abu Bakar, Ong Puay Liu \& Suhaimi Salleh (Eds.). Karya Darma II: Kemanusiaan dalam pembangunan. Bangi: Penerbit Fakulti Sains Pembangunan, Universiti KebangsaanMalaysia.

Mostafa Kamal Mokhtar. (2000). Pembangunan generik: Permasalahan ontologi epistemologi dan metodologi. Dlm. Misran Rokimin, James Francis Ongkili, Azmi Aziz (Eds.). Falsafah dan peradaban pembangunan. Bangi: Penerbit Universiti Kebangsaan Malaysia.

Muhammad 'Uthman El-Muhammady. (1987). Islamic solutions to the spiritual and moral crisis of present day society. Jurnal Pendidikan Islam, 5: 73-86.

Muhammad Zul Helmi. (2010). Kenal dan sucikan jiwamu. Kuala Lumpur: 
Mulia Terang Sdn. Bhd. Nasir Ahmad Abu Zariq. (2002). Usul AlTarbiyyah Al-Islamiyyah wa asalibuha. Amman: DarAl-Bashir.

Rokiah Ahmad. (2007). Pendidikan seks mengikut perspektif Islam. Putrajaya: Jabatan Kemajuan IslamMalaysia.

Roslan Ali \& Nosiah Fauzan. (2007). Pembangunan kerohanian danrefleksi budaya masyarakat Melayu. Sarawak: Penerbit UniversitiMalaysiaSarawak.

Rosnani Hashim. (1996). Educational dualisme in Malaysia: Implication for theory and practice. Kuala Lumpur: Oxford University Press.

Rusdin S. Rauf. (2011). Smart heart. Selangor: PTS Millennia Sdn. Bhd. Sheikh

Abdul Mabud. (1999). Can education be destructive? Muslim Educational

Quarterly 16 (2): 1-4. Sidek Baba. (2009). Fikir dan zikir. Kula Lumpur: Dewan

Bahasa \& Pustaka.

Syed Ali Ashraf. (1997). What Makes a good teacher of religious education.

Muslim

Education Quarterly, 14 (3): 1-3.

Tengku Sarina Aini Tengku Kasim \& Faridah Che Hussain. (2008). Pendekatan individu dalam pengajaran pendidikan Islam sebagai wahana melahirkan modal insan bertamadun. Jurnal Usuluddin, 27:141-156.

Tengku Sarina Aini Tengku Kasim. (2007). Proses pengajaran dan pembelajaran berkesan menurut persepektif al-Ghazali: Satu pendekatan individu. Jurnal Majlis Islam Sarawak, 1: 127-146.

Tohirin. Perspektif psikologi Islam tentang kecerdasan. Dlm. Khaidzir $\mathrm{Hj}$. Ismail. (2009). Psikologi Islam: Falsafah, teori da aplikasi. Kuala Lumpur: iBook Publication Sdn. Bhd.

Yatimah Sarmani \& Mohd. Tajuddin Ninggal. (2010). Teori kaunseling al-Ghazali: Mengenal ilmu, sejarah dan kandungan al-Quran. Selangor: PTS Islamika Sdn.Bhd.

Zaharah Hussin. (2008). Pembinaan kandungan kurikulum pendidikan akhlak untuk latihan perguruan Pendidikan Islam. Tesis Doktor Falsafah. Fakulti Pendidikan, Universiti Kebangsaan Malaysia,Bangi.

Zaizul Ab. Rahman, Zakaria Ztapa, Mohd Nasir Omar, Ahmad Sunawari Long, Faudzinaim Badaruddin, jaffary Awang, Mazlan Ibrahim, Indriaty Ismail, Norul Huda Sarnon@ Kusenin, Suzana Mohd Hoesni, Ab. Aziz Mohd Zain, Fakhrul Adabi Abdul Kadir \& Norrodzoh Siren. (2011). Faktor-faktor dalaman penyebab berlakunya jenayah rogol menurut ulama Islam di Malaysia. Prosiding Nadwah Ulama Nusantara (NUN) IV: Ulama Pemacu Transformasi Negara. Bangi: Penerbit Fakulti Pengajian Islam, Universiti KebangsaanMalaysia.

Zakaria Stapa. (1999). Pendidikan Islam dan ancaman masa kini. Pemikir Julai September: 121-153. Zawawi Haji Ahmad. (1996). Sains dalam Pendidikan Islam. Kuala Lumpur: Dewan Bahasa danPustaka.

Zimmerman, B.J. (2002). Becoming a self-regulated learner: an overview. Theory into Practice 41 (2): 64-70. Zuridan Mohd Daud. (2010). Penyucian jiwa. Kuala Lumpur: Mus Read Sdn Bhd. 